Kafkas Üniversitesi Sosyal Bilimler Enstitüsü Dergisi

Kafkas University Journal of the Institute of Social Sciences

Bahar Spring 2017, Sayı Number 19, 49-76

DOI:10.9775/kausbed.2017.005

\title{
Gönderim Tarihi:16.03.2017
}

Kabul Tarihi:12.06.2017

\section{MUALLIM NACI'NIN HEDER ADLI TIYATROSU ÜZERINE DEĞERLENDİRMELER}

\author{
Evaluations on the Play Named Heder by Muallim Naci
}

\author{
Gökay DURMUS \\ Yrd. Doç Dr., Kafkas Üni. Eğitim Fak. \\ Sosyal Bilimler ve Türkçe Eğitimi Böl. \\ gokaydurmus36@hotmail.com \\ Çalışmanın Türü: Araştırma
}

$\ddot{O} z$

Muallim Naci, Tanzimat döneminin belki de üzerinde en çok konuşulan isimlerinden birisidir. Fakat Naci'ye yönelik ilgi, onun geleneğe bağlılığından yola çıkılarak azalmıştır. Bu nedenle Naci ve eserleri, zamanın acımasızlı̆̆ına dayanamamış ve unutulmaya yüz tutmuş gibidirler. Çalışma, bu esikliği giderme adına kaleme alınmış̧ır. Çalı̧̧manın giriş bölümünde Tanzimat dönemi tiyatro etkinlikleri özetlenmistir. Ana metin, Muallim Naci ve eserin genel hatlarının tanıtılmasıyla başlamaktadır. Bir tiyatro metni olan Heder, bu bölümde, yazınsal metin çözümleme yöntemi ile tahlil edilmiştir. Tahliller, eserin konu ve tema, tür ve biçim özelliklerini de kapsamaktadir.

Heder, tezli bir eserdir. Bu nedenle son bölümde, oyunun tezleri, toplumsal ve edebî zeminde değerlendirilmiştir. Varllan yargllar, Muallim Naci'nin Tanzimat modernleşmesi içindeki rolünün sağllkl analiz edilmediğini, Heder'in ise müellifin şahsina yönelik menfî tutum nedeniyle unutulduğunu göstermektedir.

Anahtar Kelimeler: Muallim Naci, tiyatro, Heder

Abstract

Muallim Naci, is possibly one of the most mentioned names of the Tanzimat Reform Era. However, interest in Naci decreased due to his commitment to tradition. Therefore, Naci and his works have not been able to stand against time and faded into oblivion.

This study aims to make up this. In the introduction part, theater activities during the Tanzimat Reform Era are summarized. The main text starts with the introduction of Muallim Naci and his work in general. Being a theater work, Heder is analyzed through written work analysis. Analyses include the topic, theme, genre, and formal characteristics of the work as well.

Heder is a thesis work. Therefore, the theses of the play are evaluated on social and literary grounds in the last part. It is concluded that the role of Muallim Naci in the Tanzimat modernization has not been analyzed in a sound way, and Heder has been forgotten because of the negative attitude held towards its writer.

Keywords: Muallim Naci, theater, Heder 


\section{Giriş}

Bilindiği gibi tiyatro, yardımcı unsurları ile önem kazanan bir sanat dalıdır. Daha doğrusu tiyatro, "oyun (dramatik metin), oyunculuk, sahne tasarımı, giysi tasarımı, sahne tekniği ve sahneleme, ve benzerlerinden oluşan bileşken bir sanattır." (Çalışlar, 2009, s. 11)

Tanzimat dönemi modernleşme çabaları, tiyatroyu bir edebî tür ya da bağımsız bir sanat dalı olarak başkalaştırmaya çalışırken, bu bileşenleri dikkate almaz, bunların önemini kavrayamaz. Sahayla ilgilenenler, Batı'da gördüklerini özümsemeden işe koyuldukları için, dönemde gazeteye yüklenen sorumluluk tiyatro için de söz konusu olur. Gazete nasıl birtakım sosyal hedefler için vasita kılınırsa tiyatro için de aynı beklenti oluşur. $\mathrm{Bu}$ sosyal hedef, dünya üzerindeki yerini düşünemeyen ve sorgulamayan, okuma yazma bilmediği gibi, kendisini de ifade edemeyen, geniş halk yığınlarının eğitilmesidir. Namık Kemal, Mukaddime-i Celâl'de, tiyatronun insanları eğlendirdiğine dikkat çektikten sonra, söz konusu eğitim meselesine de değinir. Ona göre tiyatro, "memalik-i mütemeddinenin inkılâbât ve terekkiyâtına, neşriyâtın cümlesinden ziyade hizmetler eylemiştir." (2005, s.46) Enver Töre, bu yönüyle Tanzimat yazarlarının tiyatroyu fikirlerini açıklayabilecekleri bir "kürsü" yaklaşımı ile benimsediklerini düşünür. (2016a, s.10)

\section{Tanzimat Dönemi Tiyatro Etkinlikleri}

Modernleşme sürecimizin ilk tiyatro faaliyetleri, III. Ahmet dönemine kadar götürülebilmektedir. $\mathrm{Bu}$ dönemde İstanbul'da sefarethanelerde Fransizca sahnelenen ve sadece yabancilara hitap eden temsiller olduğu bilinmektedir. (Yalçın, 2002, s.11) 1820'lerde azınlık okullarında ve zengin Ermeni ailelerin yalılarında temsiller söz konusudur. (Yalçın, 2002, s.12) Tanzimat'ın ilanından hemen sonra, 1840'ta, Beyoğlu tiyatrolarında yabancı sanatkârlar tarafından müzikli müziksiz eserler sahnelenir ve bunları Padişah Abdülmecit de takip eder. (Sevengil, 2015, s.179) Bosko adlı İtalyan bir cambaz, 1840'ta Padişah Abdülmecit'e dilekçe vererek oyun yeri ister. Beyoğlu'nda yaptırdığ 1 binada, 1842 yılına kadar İtalyanca oyunlar sahneler. Bu oyunlarda oyuncular da İtalyandır, seyirciler ise İstanbul'daki yabanc1lar veya yabanc1 dil bilen halktır. (Sevengil, 2015, s.102-106) Bu binada 1844 yilından sonra Naum Tiyatrosu adı altında sahnelenen oyunlar söz konusudur. Mihail Naum, 1848'te binasını yenileyerek, perdelerini Macbeth ile açar. Her sezon, daha önce temsil edilen operalar ve yenilerinin sergilendiği bina, 1870 yılındaki yangına kadar Beyoğlu'nda opera zevki yaymaya devam eder. (Sevengil, 2015, s.123) 
1858 y1lı ise Türk tiyatro tarihi açısından önemli bir yıldır. Çünkü İbrahim Şinasi Efendi, Şair Evlenmesi'ni yazar. Ayrıca Naum Tiyatrosunda Riyakâr ve Müseyyip adı ile İtalyanca'dan çevrilen ilk Türkçe oyun sahnelenir. (Sevengil, 2015, s.180) Türkleri tiyatroya çekmek için Türkçe oyun sahnelenmesi gerektiği anlayışı, daha sonra Gedikpaşa Tiyatrosunu önemli faaliyetlere iter. 1868 yılından itibaren Güllü Agop tarafından yürütülen bu faaliyetlerin ilki, Leyla ve Mecnun operasıdır. 1868-1869 sezonunda Gedikpaşa Tiyatrosunda, Ahmet Vefik Paşa'nın adaptesi Zor Nikâh, 1870 yılında Âli Bey'in oyunu Misafiri İstiskal oynanır. Gazetelerde ve halk arasında Osmanlı Tiyatrosu adıyla anılmaya başlanan tiyatronun, 1871-1872 yıllarında da birçok oyun sahnelediği görülür. Bunlar içinde 1872 'de Âli Bey tarafindan dilimize adapte edilen Ayyar Hamza adlı oyun öne çıar. (Sevengil, 2015, s.227) 1873 yılı ise Osmanlı Tiyatrosu açısından önemli bir yıldır. Çünkü bu yıldan sonra Recâizâde Mahmut Ekrem, Namık Kemal, Şemsettin Sami, Ahmet Midhat Efendi gibi önemli isimler tiyatroya fiilen destek vermeye başlar. Mustafa Fazıl Paşa da malî bakımdan tiyatroyu finanse eder. (Yalçın, 2002, s.14) Bu destek sayesinde tiyatro repertuvarını geliştirir ve sayılan isimlerin oyunları da sergilenir. Âli Bey'in Geveze Berber, Ahmet Midhat Efendi'nin Eyvah, Namık Kemal'in Vatan yahut Silistre başlıklı oyunları, 1872-1873 sezonunda sahnelenir. 1873-1874 sezonunda oynanan oyunlar arasında da Namık Kemal'in Zavallı Çocuk, Âkif Bey, Mehmet Rifat Efendi'nin Görenek, Şemsettin Sami'nin Besâ yahut Ahde Vefa, gibi oyunları yanında farklı birçok oyun sayılabilir. (Sevengil, 2015, s. 239-240) 1881 yılında Güllü Agop'un tiyatro yönetimini bırakması, 1884 'te de tiyatro binasının yıkılması söz konusu oluncaya kadar, Tanzimat dönemi yazarlarımızın birçok oyunu bu tiyatroda sahnelenir.

$\mathrm{Bu}$ süreçte, İstanbul dışındaki faaliyetleri başlatmaları ve desteklemeleri açısından anılması gereken iki önemli isim söz konusudur. Bunlar; Ahmet Vefik Paşa ile Ziya Paşa'dır.

Görüldüğ̈ gibi Tanzimat dönemi yazarlarının hemen hepsi tiyatro kavramına yabancı kalmamış, çeviri ve telif eserleriyle bu türün ülkede yerleşmesi adına uğraş vermişlerdir. Ayrıca, dönem yazarları, tiyatro ile ilgili kurumsal düşünceler de üretebilmişlerdir. Şinasi, Şair Evlenmesi başlıklı ilk telif ${ }^{1}$ eseri ile bu konuda öncüdür

\footnotetext{
${ }^{1}$ İlk yerli eserin Şair Evlenmesi olup olmadığı konusunda araştırmacılar bir fikir birliğine varamamıştır. Örneğin İsmail Parlatır, Hayrullah Efendi'nin Hikâye-i İbrahim Paşa be İbrahim-i Gülşen̂̀ (1839) adlı eserini ilk yerli oyun kabul eder. Refik Ahmet Sevengil ise ad geçen oyunu, opera olduğu için, ilk yerli tiyatro eseri olarak görmez ve Şair Evlenmesi ile bu
} 


\section{Yazar ve Eseri Hakkında Genel Bilgiler}

\subsection{Muallim Naci ve Edebî Faaliyetleri}

Asıl adı Ömer olan Muallim Naci, 1849'da İstanbul Fatih'te doğar. Babası Saraç Ali Bey, annesi aslen Varnalı olan Fatimetü'-z Zehrâ Hanım'dır. ${ }^{2}$

Muallim Naci'nin okul hayatı İstanbul'da başlar, Varna'da devam eder. Varna, onun gençlik dönemini de geçirdiği şehirdir. Naci, öğrenimini tamamladıktan sonra Varna Rüştiye'sine "muallim-i sâni" olarak atanır. Onun muallimlik vasfi buradan gelmektedir. Naci bir yandan da Gülistan'1, Hafız Divanı'nı okumaktadır. Yani edebiyata ilgisi söz konusudur. Giritli Aziz Efendi'nin Muhayyelât'1nda geçen Naci sözcügünü mahlas edinmesi de bu dönemdedir. Telhis ve aruz dersleri alan, Fransızca öğrenmeye çalışan Naci, şiir denemeleri de yapar. Öyle ki Rusçuk'ta yayımlanan Tuna gazetesinde şiirleri ve makaleleri yayımlanır. Basiret gazetesi de bir mektubundan iktibas yapar ve Naci'nin bir manzumesini okurlarına dağıtır. Naci'nin Terkîb-i Bent Naziresi de 1874'te Tuna Vilayet matbaasında yayımlanır.

Muallim Naci, Osmanlı-Rus savaşı nedeniyle ailesiyle birlikte İstanbul'a gelir. Fakat İstanbul'da sürekli kalmaz. Varna'dan beri himayesini gördüğü Sait Paşa ile birlikte, Halep’ten Trabzon'a birçok il dolaşır. Yine Paşa ile birlikte Sakız'a gider. Sakız'da şiir denemelerine devam eden Naci, Tercümân-ı Hakîkat gazetesinin sahibi Ahmet Midhat ile mektuplaşmaya başlar. Gazete, Naci'nin bazı şiirlerini yayımlar. Naci, İstanbul'a döndükten sonra 1883'te, Tercümân-ı Hakîkat gazetesinin edebî sütununu yönetmeye başlar. 1884'te Ahmet Midhat'ın kızı ile evlenir. Bu dönemde Naci'nin gazete faaliyetleri yoğundur. Naci ve Mesud-ı Harâbatî takma adıyla yazdığ 1 eski tarz şiirleri, bu tarz şiirleri öven makaleleri, Fransızcadan yaptı̆̆ 1 manzum ve mensur çevirileri ile ismi tanınmaya başlar. $\mathrm{Bu}$ arada gazete, Naci'nin şiirlerine yazılan nazire ve tahmisleri de yayımlar. Artık, Tercümân-ı Hakikat, Divan şiiri geleneğinden kopamayan zümrenin ortak yayın organıdır. Bütün bu faaliyetler, eski geleneğin canlandırılması yolunda

eserin iki farklı türün ürünleri olduğunu düşünür. (Bknz: Parlatır, İsmail 2006, s. 111; Sevengil, 2015, s. 213)

${ }^{2}$ Muallim Naci'nin hayatı için yararlanılan kaynaklar şunlardır:

-Tanpınar. A. H. (1988). 19 uncu Asır Türk Edebiyatı Tarihi. İstanbul: Çağlayan Kitabevi.

- Tarakçı, C. (1994). Muallim Naci Efendi. Samsun: Furkan Kitabevi.

- Uçman, A. (1998). Muallim Naci. İstanbul: Toker Yayınları.

- Çetin, N. (2006). Muallim Naci. İ. Parlatır (Ed.) Tanzimat Edebiyatı içinde (ss. 651-701).

Ankara: Akçă̆ Yayınları. 
çabalar şeklinde değerlendirilir ve edebiyatta yeni arayışlar içinde olan zümrenin tepkilerine neden olur. Gazetede, Muallim Naci'nin başlattı̆g 1 "Meyhane edebiyatı"nın söz konusu olduğu yolundaki ifadeler sonucu da Ahmet Midhat Efendi ile Naci'nin arası açılır ve Naci 1885'te gazeteden ayrilır. Tabiî bu sonuçta, Naci'nin bu dönemde, Recâizâde Mahmut Ekrem ile giriştiği kalem tartışmaları da etkili olur. Aslında eski şiire vakıf olan ve bu geleneği inkâr etmeyen, ama Fransız edebiyatından çeviriler yapabilecek kadar yeni edebiyatı da takip eden Naci, bu dönemde hedef seçilir. Onun Batı şiirine gösterdiği ilgi ve bu şiiri özümseme çabası dikkate alınmaz, Naci yenilik çabalarına engel kesimin lideri kabul edilir. ${ }^{3}$

Muallim Naci, Tercümân-ı Hakîkat'ten ayrilınca önce Saadet ve Mürüvvet gazetelerinde çalışır, daha sonra Imdâdü'l - midâd mecmuasını kurar. Bu dönemde geçinmek için bolca yazı yazar, tercüme yapar. Bir müddet de çeşitli okullarda edebiyat ve Fransızca dersleri verir. Hayatının son döneminde kazandığı ödüllerle geçimini sağlayan Naci, Osmanlı tarihini araştırmaya ve yazmaya koyulur. Fakat tamamlayamadan 1893'te vefat eder.

Muallim Naci’nin edebî şahsiyetinin en kuvvetli yönü şiir olmakla birlikte, çalışma alanı geniştir. Bu nedenle şiir kitapları yanında, edebî tenkitleri ve sözlükleri, biyografi çalışmaları, mektup türünde eserleri, tercümeleri ve eğitim konusunda çalışmaları ile Naci, faaliyet yelpazesinin

\footnotetext{
${ }^{3}$ Nitekim araştırmacılar da Naci'nin eski geleneği canlandırmak için uğraşan zümrenin lideri olduğu yolundaki görüşlere itiraz etmektedirler. Örneğin Tanpınar, "Naci iyi okunursa, onun mutlak eski taraftarlığının bir masal olduğu görülür. Hakikatte o, iyi ve güzel mânâlarında Şark ile Garbın arasında bir fark olabileceğine inanmiyor ve milliyet perverliği bir nevi gelenek fikriyle tefsir ediyordu" der. (1988, s. 599) Mehmet Kaplan da Muallim Naci'nin gerilikle itham edilmesinin haksızlık olduğunu düşünür ve şairin, "Divan şiirini asla olduğu gibi kabul etme(diğini) onun en iyi taraflarını, kesif ifade tarzını ve musikisini" aldığını düşünür. (1988, s. 94) Fazıl Gökçek de söz konusu eski-yeni tartışmasındaki eski kavramının izafî olduğunu ve aslında Muallim Naci'nin temsil ettiği grubun Batılılaşmayı daha "mutedil bir çizgide" yürütmeye çalıştı̆̆ının anlaşılmadığını belirtir. (2007, s. 16)

Fakat bu itirazlar, Naci'nin eski geleneği savunan bir kalkan olarak kabulünü etkilemez. Örneğin Ömer Seyfettin Yeni Lisan makalesinde Muallim Naci'yi adeta hedef gösterir. Çalışma konumuz olan Heder'den yaptığı alıntılarla Naci'nin iğrenç ve ahlaksız telmihler kullandığını söyler: "Yüzlerini şarka doğru çevirerek yazan şairlerin hitaplarını, ahlarını, ohlarını, gazellerini, gözyaşlarını umumiyetle kadınlar için zannedenler bir sünnet çocuğu kadar masumdur. O neslin son şairi olan Muallim Naci'nin son neşrolunan "Heder"lerini okuyoruz. Bugünkülerin ihtimal mânasını bilmedikleri "hat-âver, çâr-ebrû" gibi tabirler görecek, bazı soğuk telmihlerini pek iğrenç ve ahlaksızca bulacaksınız." (Aktaran Enginün ve Kerman, 2011, s. 1014)

Ömer Seyfettin Naci'nin ölümünden sonra, "şark devresini hakkiyla muhafaza edecek adam kalmamış" derken de Naci'yi hakkıyla etüd edemediğini gösterir. (Aktaran Enginün ve Kerman, 2011, s. 1014)
} 
genişliğini ispatlamaktadır.

\subsection{Heder Hakkında Genel Bilgiler}

Yukarıda çalıșma yelpazesinin genişliğinden bahsettiğimiz Muallim Naci'nin tiyatro türündeki tek eseri Heder'dir. "Muallim Naci Merhumun Metrûkât-ı Kalemiyyesinden: Heder" 4 başlığıyla sunulan ve "Devr-i İstibdâdı ve Şeâir-i Milliyyeyi Musavver İki Fasıldan İbaret Tiyatrodur" ifadeleriyle okura tanttılan eser, 1326'da (1908/1909)5 İkdam Matbaası'nda bas1lır.

Yazarın bir tiyatro oyunu kaleme almasındaki nedenler, türün, Tanzimat dönemi sanatçıları arasında gördüğü rağbet ile tiyatro türüne yüklediği görev olsa gerektir. Naci, daha Tercümân-ı Hakîkat'te fiili olarak görev almaya başlamadan, tiyatro hakkında fikir üretir. Gazeteye, Naci imzasıyla gönderdiği "Tiyatronun Vucûb-ı Vucûdu ve Terakkîsi" başlıkl1 yazısında o, Avrupa ülkelerinin tiyatroya niçin değer verdiği yolundaki açıklamalarını çıkış noktası yapar. Ona göre medenî milletler, eğitim sahasında tiyatrondan da görev beklerler. Dolayısıyla tiyatro bir çeşit okuldur. Bu nedenle tiyatroya, okula devam eder gibi devam etmelidir. Tiyatronun zararları da yok değildir. Fakat bunlar yararları ile karşılaştırılınca yok denecek kadar azdır. Çünkü kişiler tiyatroda canlandırılan ulviyyeti görür ve davranışlarını ve ahlâkını buna göre terbiye eder. Örneğin; zalimler, gaddarlar, cahiller, tiyatroda karşılaştıkları hazineler ile değişebilirler. Ayrıca tiyatro gönüllere "şevk-i safâ, neş'e-i neşât" yayarak da faydalı olur. Naci, bu düşüncelerinde klasik tiyatro akımına bağlıdır. Bu akım, "tiyatronun insanların kişiliklerini geliştireceğini iler sürer." (Şener, 1991, s.123) Voltaire, Samuel Johnson gibi isimlerin geliştirdiği bu akımda, tiyatronun, "seyircinin duygularına yönelmesi,

\footnotetext{
${ }^{4}$ Metin And, oyunun başlı̆̆ için "Hazım Bey yahut Heder" ifadesini kullanır. Fakat üç ayrı nüshayı taramış olmamıza rağmen, biz eserin kapağında "Hazım Bey yahut" ifadelerine rastlayamadık. Üçünde de eser "Heder" başlığını taşımaktaydı. Nitekim And da oyundan bahsettiği diğer cümlelerinde, oyunu sadece "Heder" adiyla anar. (And, 2004, s. 97, 111, 112) Celâl Tarakçı da oyunu "Heder" adıyla tanıtırken, kaynak olarak Muallim Naci'nin arkadaşı Âfak Efendi'yi gösterir. (1994, s. 609) Yine Niyazi Akı da oyunun başlığını "Heder” olarak verir. (1989, s. 235)

Oyun, Tiyatro Bibliyografyası'nda da Heder başlı̆̆ını taşır. (1967, s. 50)

${ }^{5}$ Eserin basım tarihi ile de ilgili yanlış bir bilgi söz konusudur. Bir önceki dipnotta verdiğimiz kaynaklar dışında ,farklı kaynaklar da eserin basım yılının miladi takvimdeki karşılığı olarak 1910 yılını vermekteler. Fakat 1326 yılı miladi takvimde 1908/ 1909 yıllarına tekabül etmektedir.

6 Makale ilgili açıklamalar ve Naci'nin tiyatro ile ilgili düşünceleri konusunda Celal Tarakçı'dan faydalandık. (1994, s. 302-304)
} 
kötülükleri değil erdemli davranışları göstermesi, iyiliğe karşı sevgi ve acıma duygularını uyandırması" gerektiği düşünülür. (Şener, 1991, s. 123) Bunlar, Muallim Naci’nin de tiyatroda aradığı özelliklerdir.

Naci yazısında, Güllü Agop'un ismini anarak onun tiyatro faaliyetlerini önemser. Fakat ona göre ülkede bu alanda bir "sefalet" söz konusudur. Bu nedenle hükûmetin konuya el atması gereklidir. "Tiyatro, edebiyatın en mühim kısmıdır" diyen Naci, tiyatro eserlerinde yazarların kahramanlarını, içinde bulundukları durum ve kişiliklerine uygun olarak konuşturmaları gerektiğine inanır. (t.y., s, 73) Muallim Naci, Mektuplarım başlıklı eserinde ise Galata'da seyrettiği, Otello oyununu tahlil eder. Oyundan zevk aldığını ifade eden Naci, küçük aksaklıklardan hoşgörüyle bahseder. (1998, s. 192-194)

Naci'nin belki de bu kuramsal düşüncelerini somuta taşıyabilmek adına kaleme adlığ 1 Heder seksen sekiz sayfadır. Oyun iki perdedir ve her perdede iki sahne söz konusudur. Metnin kapak sayfasından sonra "Eşhas" başlığında kahramanlar ve sosyal hayattaki durum ve görevleri tanitılır. Oyun mensur olmakla birlikte, sık sık aralara nazım parçaları da serpiştirilmiştir.

\section{Yazınsal Metin Çözümleme Yöntemi ve Heder}

Bilindiği gibi yazının icat edilmediği ve doğaçlama yürütüldüğü dönemler dışında tiyatro, edebiyattan beslenen bir sanat dalıdır. Yani sahnelenen oyun, önce "söz"e dayalı, dilin vasıta olduğu edebî bir metindir. (Çetişli, 2009, s. 52) Çalışlar, bu durumu, "piyes" ve "temsil" kavramlarıyla açıklamaya çalışır. Çalışlar'a göre yapıt, sahnelenmek üzere hazırlandığg fakat henüz sahnelenmediği dönemde piyestir ve yazınsal bir yapıttır. Piyes, ancak sahnelendiğinde tiyatro kimliğini kazanır ve temsil hâline gelir. Çalışlar'a göre yazınsal yapıt olarak oyunlar/piyesler, yazınsal eleştiriye, yazınsal çözümlemeye tabiî tutulmalıdır. Çünkü onlar bu boyutta yazınsal estetiğin değerlendirme alanı içine girerler. Oyunlar ancak sahnelenirse tiyatro estetiği içinde değerlendirilebilirler. (2009, s. 17)

İsmail Çetişli de aynı görüştedir. Çetişli’ye göre de tiyatronun edebî metnin varlığına dayanması ve bu nedenle edebiyat sanatının sınırları içine girmesi, sahnelenmemiş oyunun edebiyat bilimi çerçevesinde değerlendirilmesini zorunlu kılar. (2009, s. 53) Dolayısıyla tiyatro oyunları, yazınsal yapıt seviyesinde iken edebiyat tenkidi ve metin tahlili yöntemleriyle değerlendirilmelidir. 


\subsection{Olay Örgüsü}

Oyunun birinci perde birinci sahnesinde başkişi Hâzım ve arkadaşları bir içki meclisindedirler. Hâzım'ın babası Mustafa Bey, Sivas'a sürülmüştür, iki yıldır oradadır. Hâzım bunun verdiği kızgınlık ve yılgınlık nedeniyle babası ile amcası arasındaki mizaç farkından dem vurmaktadır. Sözü, babasının yerine atanan mümeyyize getirir ve bundan sonra, sisteme karşı öfkesini mümeyyiz aracılığı ile kusmaya başlar. Meclisin diğer isimlerinden Kâmil Bey, onu sakinleştirmeye çalışmaktadır. Nuri Bey ise en az Hâzım kadar dertlidir. O da kalemdeki dalkavukluk yarışından, icraattan memnun değildir.

İkinci sahne, Hâzım'ın amcası ve annesi arasındaki konuşma ile başlar. Amca, Hâzım'a da kardeşine de kızgındır. Kardeşi ne kadar dediğim dedik, kurallarından vazgeçmez, doğru bildiğinden şaşmaz ise oğlu da öyledir. Amca Hazım'ı kötülerken anne, Hâzım'ın, babasının hastalığını haber veren mektuptan sonra meyhaneden çıkmadığını, eve çok geç geldiğini ve sürekli üzgün olduğunu söyler.

Hâzım gelir, yine sarhoştur ve babasının odasına gitmek istemektedir. Annesiyle giderler, Hâzım ağlayarak babasını anar. Daha sonra Hâzım, Kâmil Bey'i çağırtır. Hâzım'ın ona anlattıklarından babasının öldüğü anlaş1ır. Anne de haberi alır, evden feryat figan yükselmeye başlar.

İkinci perdenin birinci sahnesinde Süreyya Bey ile Kâmil Bey konuşmaktadırlar. Sahnenin ana mevzuu, Hâzım'ın niçin verem olduğu, döşeklere düştügüdür. Süreyya Bey, Hâzım'ın mizacını da şairliğini de beğenmemektedir. Çünkü Hâzım mümeyyize yazdığı şiirde yaptı̆̆ 1 eleştirilerle kalemdeki diğer gençlerin sergilediği ortak davranışlara ters düşmektedir. Kâmil Bey ise bu ortak davranışların ne kadar yanlış olduğundan bahsetmekte, bunların, ülkenin kötüye doğru gidişindeki payını yorumlamaktadır. Sahnenin sonunda Hâzım'ın babasının kölesi Reyhan elinde bir mektupla girer. Hâzım Bey'in tedavisi sürmekle birlikte, birkaç gündür kendisini iyi hissetmektedir.

Mektup, oyunun son sahnesinde okunur. Hâzım'ın, Nuri Bey'e yazdığı ve ölürken yanında olmasını istediği bu mektup, Nuri ve Kâmil Bey'leri çok üzer. İkisi de Hâzım'ın yanına gidip gitmeme konusunda kararsızdır. Bu sırada içeriye ağlayarak giren Reyhan, Hâzım'ın öldüğünü haber verir. İkili dövünmeye başladığında amca Ahmet Bey gelir ve Hâzım'ın biraz açıldığını, iyi olduğunu söyler. Üst üste gelen bu haberler ikiliyi şaşırtır. Nuri Bey, doğruyu öğrenmek üzere ayrılır ve biraz sonra o da 
ağlayarak geri döner. Ahmet Bey yanılmıştır, Hâzım ölmüştür.

\subsubsection{Heder'de Konu ve Tema}

Tiyatro oyunları yazınsal metin çözümleme yöntemiyle tahlil edildiğinde, konu, dramatik durum başlığıyla değerlendirilir. Oyunlarda dramatik durumlar, yani dramatik içerik, çatışmalarla yürür. Çalışlar, çatışmaları şöyle sınıflandırır: "Oyun kişilerinin hareketlerinden ve sözlerinden doğan çatışma, fiziksel çatışmadır. Oyun kişilerinin kendi kendileriyle ruhsal ve zihinsel çelişmelerinden ortaya çıkan çatışma ise, psikolojik çatışmadır. Olaylar dizisinin gerektirdiği ve oyun kişileriyle gelişip sonuçlanan çatışma, dış çatışmadır. Oyunun içeriğinde yatan, yani dramatik durumdan kaynaklanan çatışma iç çatışmadır." (2009 s. 22)

Heder'de dış çatışma, yani dramatik metnin dışında gelişen ve olayların başlangıcını tetikleyen çatışma, Mustafa Bey'in sürgünüdür.

Dramatik durumun inşa edildiği iç çatışma ise oyunun başkişisinde vücut bulan durumlardır. Bunlar, hayatın kendi paradigmalarından doğan karmaşık ilişkiler ve yönelimlerdir. Hâzım'ın yaşadığı dönemin dejenerasyonuna, değişen kültür algısına yönelik tepkileri, eleştirileri ve bunları içselleştirerek yatağa düşmesi iç çatışmadır. Bu iç çatışma, Hâzım aracılığı ile umuda evrilebilecekken, yazar tercihini farklı yönde kullanır. Hâzım toplumsal pratiği düzenleyecek ve değişime zorlayacak bir karakter olarak kurgulanmaz. Bu yüzden de oyundaki çatışmalar çözüme ulaşamaz, okur nazarında belirsizliğe kapı aralar. Bu, aynı zamanda Hâzım'ın ve diğer kahramanların kendi ruh ve zihinlerinde yaşadıkları çelişkilerin yansıdı̆̆ psikolojik çatışmalarla da desteklenen bir oyun sonudur.

Dramatik metinlerde konu, tema tarafından desteklenir. Yani, "tema, dramatik durumun arkasında yatar, dramatik durumu öne çıkarır." (Çalışlar, 2009, s. 25) Heder'de tema, sosyal toplumsal düzene ve dönemin edebî anlayışına karşı geliştirilen tepkidir. Bu tepki, Hâzım ve çevresindeki insanların yaşam tarzlarına nüfuz eder ve onları birtakım davranış ve fikirlerin sahiplenicisi olmaya iter. Dolayısıyla Hâzım ve çevresinin çatışmalar üzerine kurulu yaşamları Heder'in konusudur. Bu çatışmaların doğduğu ve aşağıda tahlil edilecek zemin ise Heder'in temasıdır.

\subsubsection{Heder'de Tür ve Biçim}

Aristoteles'ten beri tiyatronun komedya ve tragedya olmak üzere iki ana ve birbirinden farklı türü olduğu kabul edilmektedir. (Şener, 1991, s. 85, 109) Klasiklerin de bağlandığı bu görüş, romantik tiyatro kuramcıları tarafindan esnetilir ve alt türler söz konusu olur. (Şener, 1991, s. 169) Fars, 
melodram, ciddi oyun gibi ikincil oyun türleri tragedya ve komedyanın türevi olarak kabul edilen yeni türlerdir. (Çalışlar, 2009, s. 58-63)

Tanzimat dönemi oyun yazarlarımız bu yeni türler içinde, en çok melodrama rağbet gösterirler. Çünkü melodramlar hem yazarların amacına, hem çağın anlayışına en uygun türlerdir. (Çamurdan, 2015, s. 17; And, 2004, s. 108)

Heder de melodram türünde bir oyundur. Çünkü Muallim Naci, melodramların genel yapısına uygun şekilde, oyunu toplumsal bir işlev adına kurgular. Ortada, Doğu ile Batı geleneksel ile yeni arasında bocalayan bir halk olduğuna göre, yazarların ona biçim vermesi, doğru yolu göstermesi, onu eğitmesi gereklidir. Muallim Naci, melodramların "halkın ahlaksalduygusal eğitiminin bir aracı" olması gerektiği tezi ile hareket etmiştir. (Çalışlar, 2009, s. 60) Bu tezin hangi saptamalarla işlendiği aşağıda tahlil edileceği için, Heder'i niçin melodram kabul ettiğimizi açıklamaya devam etmekte yarar var.

Öncelikle oyun, başlı̆ğ ile türün işlevine hizmet eder. Melodramlarda başlık, seyirciyi veya okuyucuyu neyin beklediğine işaret eder. Başlı̆̆ın "Heder" olması, okuru oyun sonunda parçalanmış hayatlarla karşılaşılabileceği tezine hazırlar ve nitekim Hâzım'ın hayatı heder olur.

Melodramlarda amaç "erdem dolu suçsuzluk ile suç dolu kötülük arasındaki gerilim"i, etik çatışmayı ortaya koymaktır. (Çalışlar, 2009, s. 60) Yukarıda da belirttiğimiz gibi Heder'de çatışmalar çok boyutludur. Hâzım ve arkadaşları ile karşı tarafta kümelenen grup arasındaki etik çatışma, oyunun özünü oluşturmaktadır. $\mathrm{Bu}$ "erdem dolu suçsuzluk" durumu melodramlarda, giriş bölümü ile birlikte tehdit görmeye başlar. Hâzım'ın oyunun girişi sayılabilecek birinci sahnede yaptı̆̆ açıklamalar, oyunda söz konusu tehditleri de ortaya sermektedir. Babas1 sudan sebeplerle İstanbul dışına sürülmüşken, kendisi de babasının yerine geçen mümeyyiz tarafından etkisiz kılınmak istenmektedir.

Hâzım'in bu tehdidin saçmalığ1 ve muhtemel karşılıksızlı̆̆ 1 için ortaya koyduğu tespitler ise Muallim Naci'nin yaşam algısından ve edebî anlayışından izler taşır. Bu yönüyle Heder, Tanzimat melodramlarının bir başka boyutuyla daha ortaktır. Şöyle ki bu oyunlarda, yazarlar, "öğretici ve dayatmacı bir duruş" (Çamurdan, 2015, s. 21) sergiledikleri için, onların seyirciye/okuyucuya aktardıkları genel ve kesin yargılar, sorgulanamaz, mutlak değerlerdir. Heder bu tarz mutlak değerler konusunda zengin bir oyundur. Ayrıca yargıların sorgulanamaz oluşu melodramlarda bir 
teksesliliğe neden olur. Heder'de amca Ahmet Bey ile Süreyya Bey'in oyuna hakim genel tezler aleyhindeki düşünceleri bertaraf edilirken gerçekten de bir tekseslilik söz konusu olur. Muallim Naci'nin sözcü seçtiği kahramanların doğruları tek ve nettir.

Klasik melodramlarda, okurun/seyircinin merakını canlı tutacak önemli bir öge söz konusudur. Bu, "Yanlış Haber/Yanılgl ile Kimlik/Kılık Değiştirme"dir. (Çamurdan, 2015, s. 96) Heder'in son sahnesinde Reyhan Ağa ile amca Ahmet Bey tarafından getirilen yanlış haberler söz konusudur. Hangisinin doğruyu söylediği tartış1lırken merak duygusunun ivme kazandığ1 bölümde, yanlış haber, beklenmedik bir olaya zemin hazırlar. Okur, Hâzım'ın iyileştiğini düşünürken, öldügünü öğrenir.

Oyunların melodram türü içinde değerlendirilmesini gerekli kılan bir diğer öge şahıs kadrolarıdır. Ayrıntılı şekilde "Şahıs Kadrosu" başlığında tahlil edilecek Heder kahramanları, iyi ve kötüyü canlandıran tipleşmiş kişilerdir. $\mathrm{Bu}$ bağlamda Hâzım melodram türünün "masum çocuğu" (Çalışlar, 2009, s. 61) iken Süreyya ve Ahmet Bey'ler, kötü’nün temsilcileridir. Hâzım'ın babası Mustafa Bey ise melodramların olmazsa olmaz kahramanlarından "Saygın baba" (Çalışlar, 2009, s. 61) tipini örnekler. Yalnız, melodramların kahramanlar konusunda eksik noktası, onların kendilerine özgü kişiliklerinin olmamasıdır. Çünkü melodramlarda kişileştirme "söylem ve eylem bağlamında değil, ülküsel tiplemelere göre yapılır." (Çamurdan, 2015, s. 38) Bu nedenle abartılmış özellikler taşıyan melodram kahramanları, kendiliğinden iyi veya kötüdür. Onların ruhsal durumları, neden-sonuç ilişkisinden kopuk bir bağlamda tahlil edilir. Örneğin Kâmil Bey'in, Hâzım'a niçin yardım etmek istediği veya niçin bu tarz bir kişilik olduğu yolundaki soruların, oyunda cevabı yoktur. Onun Mustafa Bey'in arkadaşı olduğu gerçeği, sorunun cevabını karşılamamaktadır. Ya da Hâzım içinde bulunduğu sosyal/toplumsal düzene karşı eleştiri getirirken onun, niçin bu eleştirileri faaliyete dökemeyecek kadar zayıf bir karakter olarak kurgulandığı sorusu da cevap bulamamaktadır.

Melodramlar iyi ve kötü çatışması bağlamında türlere ayrılırlar. Sonu kötü biten melodramlar, "yenilgi melodrami" olarak kabul görür. (Çalışlar, 2009, s. 60) Heder, sonu kötü bittiği için bir yenilgi melodramıdır.

Bütün bu açıklamalarla bazen örtüşen bazen ayrışan birtakım tespitler de Metin And'a aittir. And, Heder'i, "duygusal ve evcil" dram türünde bir oyun olarak kabul eder ve gerekçesini şöyle açıklar. (And, 2004, s. 10) Ona göre bu oyunlarda aşırı duygusallık ve acındırma söz konusu 
olup, bunun nedeni aşk acısıdır. Heder, kahramanlarının aşırı duygusallı̆̆ 1 ile ön planda olup trajik bir sonla bitmesine rağmen, aşk acısının söz konusu olmadığı bir oyundur. Dolayısıyla bu tespitin, ancak ilk ayağı Heder için geçerlidir. Fakat And'ın bu oyunlarda toplumsal sorunlara da değinildiği yolundaki tezi, Heder ile birebir örtüşür. (2004, s. 111) Bu noktada akla "Heder melodram midir duygusal evcil bir dram midır" sorusu gelecekse de Çamurdan'a ait bir tespit kafalardaki bulanıklığı gidermektedir. (2015, s.17) Çamurdan, Tanzimat yazarlarının melodramlarda dramatik ögeler de kullandığını ifade ederken Heder'in, her iki türün de özelliklerini taşıdığı yolundaki algıyı desteklemektedir. Nitekim And'ın, Heder'i çağının ilerisinde bir oyun olarak görmesi, her iki türün de özelliklerini taşıyor olması kaynaklıdır. And, Heder'i şöyle tanıtmaktadır: "Gene duygusal bir dram türünde ancak ötekilerden olabildiğine değişik havada, çağının çok ilerisinde bir dram da Muallim Naci'nin Heder'idir. Genç bir şair, çağındaki düzen bozukluğu, inançsızlık, toplumdaki iki yüzlülük, inançsızlık karşısında yabancılaşır, yalnızlaşır ve duyduğu acıyla ölür." (2004, s. 112)

Yazınsal tiyatro metinleri açık ve kapalı olmak üzere iki biçimde kaleme alınır. Biçim, oyunun dış yapısıdır. Heder, kapalı biçimle kurgulanmış bir oyundur. Kapalı biçimlerdeki oyunlarda "olaylar birbirinden gelişerek oyunun kapalı bütünlügünü kurar, sürekli olarak bitişe doğru gider." (Çalışlar, 2009, s. 26) Nitekim Heder'de başlığı duyunca beliren facia beklentisi, olaylar geliştikçe kuvvetlenir. Kapalı biçimdeki oyunlarda oyun sahneleri birbirini doğurur, her sahne sonrakine zemin hazırlar. Heder'de örneğin Hâzım'ın birinci sahnede yaptı̆̆ eleştiriler, bir başkası tarafından da teyit edilmesi gerektiği için ikinci perdenin ilk sahnesi kurgulanır. Burada Süreyya Bey'in merkezinde olduğu düşüncelerle, doğrunun Hâzım olduğuna dikkat çekilir. $\mathrm{Bu}$ durum kapalı biçimdeki oyunlarda oyun kişilerinin birbirleri için var oldukları şeklindeki tezle de örtüşür. (Çalışlar, 2009, s. 26) Hâzım ve Süreyya birbirlerinin zıddı kahramanlar olarak çizilirken karakterlerinin toplumdaki yansımalarını da örneklemektedirler. Yine Mustafa Bey'in ölüm haberi öncesinde, hastalığının duyulması da Heder'in bir bitişe doğru gittiğini ve kapalı biçimde kaleme alınan oyunlardaki sahneler arası paralel ilişkileri örneklemektedir.

\section{2. Şahıs Kadrosu}

\section{Hâzım}

Heder, kısa bir oyun olduğu için şahıs kadrosu kalabalık değildir. Oyunun başkişisi Hâzım yirmi üç yaşında bir gençtir ve evin tek çocuğudur. 
Şair yaradılışlı olan bu genç, bir kalemde memurdur. Oyunun aktüel zamanında Hâzım, aşırı duygusal, alıngan bir mizaca sahiptir ve onun bu mizacını besleyen birtakım olaylar söz konusudur. Babası hak etmediği bir biçimde ve istemediği hâlde sürgüne gönderilmiş, bu durum Hâzım'nn hayata bakış tarzını çok etkilemiştir. $\mathrm{O}$ artık hayatta daima, tembelliğin, dalkavukluğun, kötülüğün rağbet gördüğünü anlar. Bu durumu, babasının yerine geçen mümeyyizin, Hâzım'dan dalkavukluk beklemesi de tetikler. Ama Hâzım bu beklentiyi boşa çıarır, mümeyyize taşlamalarla dolu bir gazel yazar, kalemi terk eder. Babasının Sivas'ta hasta olduğu, ardından öldüğü haberleri ise onu hayattan iyice soğutur, bahtsız olduğuna inandırır ve verem döşeklerine düşürür.

Hâzım başına ne gelirse gelsin, inatçı, kararlı ve bildiğinden şaşmayan bir kişiliktir. Bu yönüyle o, örnek bir tiptir ve "doğru"nun temsilcisidir. "Ben insanlığı bırakıp da statü olamam" (s. 6) ${ }^{7}$ diyen bu genç için, doğru, insanlığa yararlı olan, haysiyet ve ulviyeti yükseltecek faaliyetler yapmaktır. $\mathrm{Bu}$, onun entelektüel kişiliğinden kaynaklı bir zorunluluktur. Hâzım hem Arapça, Acemce hem Fransızca bilen bir gençtir. Dolayısıyla geleneksel olana da modern olana da aynı seviye ile yaklaşmakta, ikisi arasında bir sentez ön görmektedir. Onun bu çok boyutluluğuna, kendisinden çok zıt bir mizaca sahip olan amcası dikkat çeker. Amca, Hâzım'1, bir hocaya götürmeyi, böylelikle yiyeninin, hocanın himmetinden faydalanmasını sağlamayı teklif edince Hâzım, şiddetle karşı çıkar ve insanoğlundan himmet ummadığını söyler. (s. 34) Amca sinirlenir, fakat Hâzım'ın hakkını da teslim eder. Hâzım, Fransızca bildiği gibi, "Mesnevi-yi Şerif'ten beyitler, Fütuhattan, Füsus'tan ibareler" de okuyabilmektedir. (s. 84) Amcanın şaşkınlığını Kâmil Bey giderir ve Hâzım için "her şeyi bilen hamiyyetli gençlerimizdendir" ibaresini kullanır. (s. 84)

Hâzım'ın bu entelektüel kişiliği, kararlılığı sert bir mizaçla birleşebilseydi muhakkak ki oyunun seyri farklılaşırdı. Fakat Muallim Naci, Hâzım'1, ağlamaya meyilli, içkiye düşkün, duygusal mizaca sahip bir kahraman olarak çizer. Yazar bu tercihini haklı göstermek için yine Hâzım'1 kullanır. Annesinin Hâzım'a, niçin bu kadar üzgün durduğunu sorduğu sahnede Hâzım, başka seçeneği olmadığını, "Dâr-ı matemde oynamak elimden gelmiyor" ifadesiyle açıklar. (s. 48)

\section{Mustafa Bey}

İsmi geçtiği hâlde oyunda aktif görev almayan bu şahıs, Hâzım'ın

\footnotetext{
7 Oyundan yapılan alıntılar, Osmanlıca nüshasına göre sayfa numaraları verilerek aktarılacaktır.
} 
babasıdır. Hâzım'ın bilip isteyerek “peyrev" olduğu (s. 6) Mustafa Bey için hayattaki en ulvi eylem çalışmaktır. O "her şeyin sa'ye bedel kazanılmış lazım geleceği fikr-i âlisini yine sa'y ile hasıl etmiş" bir zâttır. (s. 4) Bu yönüyle de oğlunu büyüler. Hâzım'a göre babası, "ehliyetten, istikametten, hakk-guluktan" (s. 6) ayrılmadığı için Sivas'a sürülür. Bu sürgün Mustafa Bey'in hakkı olmadığı için, Hâzım'ı da etkiler, hayata küsmesine neden olur.

Hâzım, halkını doğru yola iten fakat arkasına ancak birkaç kişi alabilen peygamber kadar mahzun bulduğu babasının ögütlerini de değerli bulur. (s. 51) Babası ona aklını kullanmakta hür olduğunu, iyiyi kötüyü kendisinin ayırt etmesi gerektiğini söylemiştir. Hâzım'a, çoğunluğun saptığı yanlış yollara, azınlıkta kalma pahasına, meyletmemesini öğütlemiştir. Hâzım bunu başarır, fakat zayıf yaradılışı yüzünden hedefini şaşırır. Baba oğulun, hatıralarla metne dahil olan bu konuşmaları, Tanzimat aydınının, toplumsal dejenerasyona dair umudunun devam ettiğini göstermesi bakımından önemlidir.

\section{Kâmil Bey}

$\mathrm{Bu}$ umudu dillendiren bir başka kahraman da Kâmil Bey'dir. Mustafa Bey "esdekasindan" sifatıyla tanıtılan ve Mustafa Bey'den bir iki yaş küçük olan (s. 9) Kâmil Bey oyunun bilge kişisidir. Çünkü her sıkıntısında Hâzım'ın yanında olan, onu ferahlatmaya çalışan Kâmil Bey'dir. Üstelik bunu herhangi bir zorunluluktan dolayı yapmaz. Onun mizacı da Mustafa ve Hâzım Bey'lerle aynıdır.

Kâmil Bey, Hâzım'1 hayata bağlamak için giriştiği diyaloglar dışında, Süreyya Bey'le yaptığı sohbette de bilge kişidir. Ülke için firsat zamanlarının geçtiğini düşünen bu zâta Kamil Bey, herkesin üzerine düşeni yapmas1 durumunda, "Bekâ-yı milliyet, Bekâ-yı devlet" meselelerinin eninde sonunda çözüm bulacağını söyler. (s. 69, 70)

\section{Nuri Bey}

"Hâzım Bey'in muhibb-i sadıkı" sıfatıyla tanımlanan bu zât, Hâzım'1 gerçekten de çok sever. O da Hâzım gibi bir kalemde memurdur. Tek ortak yönleri bu değildir. Nuri de kalemde haksızlığa uğramış, bunu gururuna yediremediği için kendisini içkiye, şiire, sohbete vermiştir. "Bendeniz dalkavuk değilim ... Dalkavuk olaydım tefeyyüz ederdim" (s. 19) diyen Nuri, Hâzım ve Kâmil Bey'ler gibi aynı zamanda edebiyattan ve musikiden de anlamaktadir.

\section{Ahmet Bey}

Hâzım, amcası olan bu zâtı hiç sevmez. Çünkü o babasından çok 
farklı bir mizaca sahiptir. Hâzım'ın babası ne kadar çalışıp didinmek gerektiğine iman etmişse Ahmet Bey o kadar miskin ve tembel olmayı gerekli görür. (s. 6)

Aradaki mizaç farkı nedeniyle kardeşini de Hâzım'1 da tasvip etmeyen bu amca, paraya düşkün, zamaneye uymuş, bir zâttır. (s. 5) Tasavvufla meşguldür, kadercidir ve bu yönüyle softadır. (s. 83-84) Bu nedenle, Avrupa'dan örnek alınabilecek her türlü çağdaş yaşam unsuruna karşıdır.

\section{Anne}

Hâzım'ın annesi Latife Hanım, şanssız bir kadındır. Kocasının sürgüne gönderilmesi yetmezmiş gibi oğlu da meyhanelerden çıkmamaktadır. Hâlbuki Hâzım, onun bu dünyadaki tek hazinesidir. Bu nedenle de Hâzım'1 hayata döndürmek için evlendirmeyi düşünür, bu konuda amca Ahmet Bey'den yardım ister. Dolayısıyla Latife Hanım, Tanzimat melodramlarındaki kadın imgesinin temsilcisidir. (Çamurdan, 2015, s. 46) Bu temsilciler toplumun benimsenmiş düzenine, koşullarına karşı alternatif geliştirebilecek kahramanlar değildirler. Bu yüzden öne çıkan özellikleri eş ve anne rolleridir. Hem kocasını hem oğlunu kaybeden kadının feryat figanı da bu kanıyı desteklemektedir.

\section{Süreyya Bey}

Hâzım, Nuri ve Kâmil Bey'lerin tam zıddı bir karaktere sahip olan Süreyya Bey, bu üçlünün değer verdiği her türlü ilkenin karşısındadır. Kalemde yaptığı dalkavukluklar sonucu rütbe sözü alması bunun delilidir. Rütbeyi "etek öpmekle dudak aşınmaz" anlayışı ile kapmıştır. (s. 61) Süreyya Bey'in devletin ve milletin geleceğine, toplumun aksak yönlerine dair hiçbir teklifi yoktur. Çünkü bunlar onun önem verdiği meseleler değildir.

\section{Sabri Efendi}

Bu kişi, Heder'de oyun kişileri kümelenirse Süreyya Bey kümesine girer ve bunu ispatlar şekilde "Bir müdahin" sıfatıyla tanıtılır. Onun ilk sahnede söylediği riyakârlık kokan sözler, davranışlar, Nuri ve Hâzım'1 rahatsız eder. Nuri bu nedenle onu "erbâb-ı nifak"tan sayar. (s. 30)

\section{Reyhan Ăga}

Mustafa Bey'in kölesi Reyhan, Hâzım ve annesine de bağlıdır. Bu nedenle Hâzım'ı merak eden, arayan, mektuplarını taşıyan odur. Son sahnede Hâzım'ın öldüğünü hıçkırarak anlatır. 


\subsection{Dil ve Üslûp}

Heder amacı ile tarzı arasında çelişkiler söz konusu olan bir oyundur. Bu çelişki öncelikle yazarın dil ve üslûbundan kaynaklanmaktadır. Amca ile annenin, gayet masumane biçimde Hâzım'1 çekiştirdikleri bölüm dışında, oyunun dili oldukça ağırdır. Edebî muhabbetlerin söz konusu olduğu sahnelerde dil iyice ağırlaşır. Bu sahnelerde Farsça okunan beyitler ve şiirler bunun kanitıdır.

Örneğin 52. sayfadaki ifadeler, Hâzım'ın babasının düşmanlarını yermek için kullandığı sözlerdir. "Zavallılar bilmezler ki... Pederin böyle çekilmesiyle teşeffi edenler az midır? Ben de babamı takip edersem ikmal-i teşfi etmiş olurlar daha ziyade sevinirler... Zavallılar bilmezler ki giriftâr oldukları maraz-ı ruhâni kendilerini, müteverrimin son inbisâtı tarzında ferah-nâk ediyor!..." Amacı okuruna/seyircisine bir mesaj vermek ve onun hayatında bir pencere açmak olan yazarın, niçin böyle ağır bir dil kullandığg merak konusudur.

Heder bu yönüyle Ömer Seyfettin'in Yeni Lisan makalesine de konu olur. Ömer Seyfettin, daha önce dipnotta alıntıladığımız sözlerinde, yukarıda geçen "ferah-nâk" tarzı ifadeleri eleştirir, hatta iğrenç ve ahlâksızca bulur. "İgrenç ve ahlaksız" ifadeleri bize göre ağır ithamlardır. ${ }^{8}$ Ömer Seyfettin'in bu sözlerinin devamında, Heder'in dilinin dönem nesli tarafından anlaşılamayacağını söylerken ise haklıdır. (Aktaran, Enginün ve Kerman, 2011, s. 1014)

\section{Heder'de Sosyal Toplumsal Boyut}

Heder'in başkişisi Hâzım, babasının ölümünü duyunca onu bir peygambere benzetir. Ona göre, babas1, senelerce "tarik-i hakta" (s. 51) uğraşmış mahzun bir peygamberdir. Hâzım'ın "tarik-i hak" kavramıyla nitelediği fikir, "ittihat" fikridir. Bu fikir, Heder'in sosyal boyuttaki tahlillerinin çıkış noktasıdır. Öncelikle oyun kahramanları, Osmanlı toplumunun ittihat fikrini kaybettiğini, çağın yaşam tarzının, bu fikrin anlamsızlığını ortaya koyan bir işaret olduğunu düşünürler. Örneğin Hâzım, “Asrımızda, ittihat! Ne lafz-ı bî mana!...” der. (s. 51) Hâzım'a göre bu manasızlık, ülke insanının vatan mefhumuna bakışını da değiştirmiştir. Vatan topraklarının kaybı artık kimseyi etkilememektedir: “...Vatanın bir

\footnotetext{
${ }^{8}$ Nitekim Fevziye Abdullah Tansel de bu ithamları ağır bulduğu için Ömer Seyfettin'in Heder'i okumadan karar verdiğini düşünür. Tansel, F. A. Muallim Naci ile Recaizade Ekrem Arasındaki Münakaşalar ve Bu Münakaşaların Sebep Olduğu Edebî Hadiseler. 06.01.2016. tarihinde www.journals.istanbul.edu.tr/iuturkiyat/article, adresinden erişildi.
} 
parçası gidiyor da kimsenin kaydında olmuyor... Böyle facialardan müteessir olmak için insan yüreği ister!” (s. 45)

Hâzım'ın duygu ve düşüncelerindeki dağınıklığa bağlı olarak, cümlelerinin arasına serpiştirdiği bu umutsuz bakış açısını, ancak, eserin bilge kişisi Kâmil derli toplu ifade eder. Ona göre Osmanlı toplumu mevkiinin farkında olmayan, örneğin şanlı geçmişini dikkate almayan bir toplum hâline gelmiştir. Bu nedenle de ülkede dirlik ve birlik kalmamış, ülke insanı birbirini alt etmeye çalışırken, asıl düşmanlar bundan nasıl faydalanabileceklerini görmüşlerdir: “... Şu 'mevkiimiz' kelimesine dikkat olunuyor mu? İşte biz bu kelimenin manasını vaktiyle bilmiş olaydık. Düşman bize nasıl galebe edeceğini düşünmekte iken, bizi girdab-ı inkıraza doğru sürüp götürmek için muvafik rüzgâr gözetmekte iken önümüzü ardımızı kaybedercesine zevke dalmayaydık. Nazar-ı intibahımızı açacak yerde, kör dövüşü tarzında birbirimizle uğraşmayaydı. Herif ötede bizim bağrımızı delmek için kurşun fişengi yaparken, biz burada heva-yı fişenk uçurarak eğlenmekle ve en mühim işimiz olmak üzere muhafaza-i ikbal-i vatana bedel ikbal-i şahsı muhafazasına çalışmakla vakitleri zayi etmeyeydik! Hülasa, mevkiimizin îcâbâtını bilip de ona göre hareket edeydik? Şimdi kendimizi şu hal-i acz-ü fütur içinde bulmazdık" (s. 67)

Kâmil Bey'e göre Osmanlı toplumu ittihat fikrinden öylesine kopmuş, öylesine derin ayrışmalar yaşamaya başlamıştır ki toplumda,"...Türk evladindan madûd olmaktan ar edecek kadar alçak yadigârlar" zuhur etmiştir. (s. 68)

Osmanlı toplumu "bekâ-yı milliyet bekâ-yı devlet" (s. 69) adına çalışmadığ 1 , vatanperverâne duygulara kapılmadığı için (s. 70) yaşanan bu durum, Kâmil Bey'e göre Allah katında da kabul görmez. Çünkü Allah, birlik için çalışanın yanındadır: "Tevfik-i Illahi Sa'y ü ittihat erbabına münceziptir.” (s. 70) Allah'ın takdirini kazanmak düşüncesi, büyük küçük herkesi tetiklemeli ve "efkârın nokta-i iltikası" bir olmalıdır. Fikirde, işte, birlik beraberlik için uğraşmayanlar ise Kâmil için ölmeleri yaşamalarından daha hayırlı olanlardır: "Ah keşke öyle yüz bin adamımız olsa da efkâr-ı umumiyeyi tashih ve için çalışa çalışa teverrüm etseler de ölseler! Efkarı sihhat ü ittihattan arî bir milyon nüfusumuzun yaşamasından hayırlı olurdu! (s. 68)

İttihat fikri, tüm ülkenin ortak hedefi olmalıdır. Fakat örneğin babası Hâzım'1 özgür bırakmış ve kendi fikirlerini kendisinin olgunlaştırmasını 
istemiştir. ${ }^{9}$ (s. 56) Babanın Hâzım'ı gönül rahatllğıyla özgür bırakma nedeni, oğlunun kendisine ne kadar benzediğini görmüş olmasıdır. Babası Hâzım'a, ülkenin birlik beraberliğe ihtiyacı varken ayrışmalar yaşanmaya başladığını söylemiştir. $\mathrm{Bu}$ ayrışma azınlık ve çoğunluk ayrışmasıdır. Çoğunluk değerlerini kaybetmiş, Avrupa meraklısı olup çıkmış kesimdir. Babası Hâzım'a, iyiyi ve doğruyu sağlıklı tayin etmesini, sırf çoğunluktalar diye o gruptan olmamasını öğütlemiş̧tir: "Servetim olsa gider Avrupa'da yaşardım, diyenlerden olma." (s. 57) Çünkü babaya göre, eğer ülke yaşanmayacak hâlde ise kaçmak çözüm değildir. Kalmalı, savaşmalı, fikirleri birleştirmeye, eserler ortaya koymaya çalışmalıdır: "Memleketin seni kaçıracak kadar bedbaht ise onu o halde birakıp da savuşmak laylk mıdır? Sahih ve metin fikrin varsa, elinden iş gelirse mümkün olduğu kadar vatanda ıslah-ı efkâra çalış, vatanda izhar-ı asar et." (s.57)

Tarihsel süreç bu tespitlerin belki de Osmanlı toplumunun dağılmasını önleyebilecek çözümler içerdiğini göstermiş olmakla birlikte, Heder'de ilgi çekici bir boyutu yok saymamıza neden olamaz. Tespit ve teklif sahibi bu kahramanlar, eylem boyutuna asla geçemezler. Üzülür, düşünce üretir, çözüm sunarlar, ama sahada etkisiz kalırlar. Bu eksikliği en sağlam şekilde yine Kâmil Bey tahlil eder. Ama onun da ülkenin ihtiyaç duyduğu dirlik ve birliği bozan ahlaksızlara karşı elinden bir şey gelmemektedir: "Ah! Elimden gelse de şu azm-i kat'îyi iltizam edenleri istihza edecek kadar ahlakı bozulmuş olanlarımız yeryüzünden kaldırsam! Bunların mahvı uslahından kolaydır!" (s. 55)

$\mathrm{Bu}$ çaresizlik, Heder'in toplumsal boyutunun yön değiştirmesi anlamında da gelir. Artık eserin merkezinde "kaht-ı rical" kavramı durmaktadır. Adam kıtlığı, adamsızlık manasındaki bu söz, özellikle Tanzimat sonrasında sosyal hayatta çokça kullanılmış bir ifadedir. Nitekim Namık Kemal de bu sorundan büyük bir önemle bahseder. (Ulçugür, 1982, s. 129)

Heder'de kavram, Kâmil Bey aracılığıyla dillendirilir. Kâmil Bey, Osmanlı Devleti'nin yetişmiş elemanına değer vermediğini, bu nedenle "kaht-ı rical" derdine uğradığını düşünür. (s. 65) Ona göre Osmanlı Devleti, milletine devletine yürekten hizmet etmeye azimli olan kişilere, ancak zulüm

\footnotetext{
${ }^{9}$ Heder'de babasının Hâzım'ı fikirlerini oluşturması için özgür bırakması durumu, Enver Töre'ye göre Tanzimat oyunlarının ortaklık kurduğu bir konudur. Töre'ye göre Tanzimat yazarları, ferdi hürriyetini elde edememiş kişilerin toplumun hürriyetini de sağlayamayacağını düşünürler. $\mathrm{Bu}$ bağlamda Heder, Töre'nin, "Konusunu Tanzimat'in Siyaset ve Uygulamalarından Alan Piyesler" başlı̆̆ında tahlil ettiği metinlerle bağdaşıtır. (2016b, s. 39)
} 
reva görmüștür. Onlardan birisi de Hâzım'ın babası olan ve kendisinin de büyük muhabbet beslediği Mustafa Bey'dir. Fakat Mustafa Bey'in kıyıma uğraması en çok Hâzım'1 etkilediği için, bu kıyımın sebep ve sonuçları ile ilgili doğru tespitleri Hâzım yapar. Hâzım “ “.. ehliyetten, istikametten, hakkguluktan" (s. 6) başka ilkesi olmayan babasının Sivas'a neden sürgün edildiğini anlamlandıramamaktadır. Eğer babası bir hain ise Sivas'ta karakteri mi değişecektir, hain değilse niçin sürülmüştür? (s. 7)

Hâzım'a göre bu kıyımın ülkeye uzun vadede olumsuz getirileri söz konusu olacaktır. Çünkü yetişmekte olan gençler ve halk bu durumdan rahatsızdır: "Yetişmiş adamları tahkiren öyle şuraya buraya atıvermek yetişecekleri de istikbâlinden bîzâr ediyor. Müfsidlerin, hainlerin işte bulunmalarına müsaade göstermek halkın rahatını, emniyetini bütün bütün selb ediyor." (s. 8)

Osmanlı'nın içinde bulunduğu çöküntünün önemli sebeplerindendir kaht-1 rical. Çünkü bir devlet, ancak ona gönülden bağl1, her zaman kendinden önce devletini düşünecek, ehliyet sahibi insanların omuzlarında yükselir. Osmanlı, topraklar fethetmiş, sınırlarını geniş̧letmiş, fakat bu sınırları muhafaza edecek değerli elemanlarını koruyup kollamamıştır. Bu düşüncelerin sözcüsü Hâzım'dır ve yine babasının uğradığı haksızlığın toplumun kanayan önemli yaralarından biri olduğuna vurgu yapmaktadır: ${ }^{10}$ "Adama vatan lazımsa vatana adam elzemdir. Adamı vatan beslerse vatana adam hayat verir. Adam vatansız yaşayamazsa vatan adamsız hiç yaşayamaz. Ecdadımız bu kadar yerlerin fatihleri olmuşlar, dünyayı sarsmışlar, şöyle yapmışlar, böyle etmişler, diye iftihar etmek isteriz. Istediğin kadar fethet muhafaza edecek adam olmadiktan sonra! Adam yetiştirmedikten sonra!" (s. 45, 46)

Kâmil Bey de Hâzım gibi, ülkelerin büyük adamların omuzlarında yükseleceğine inanır: "Bir millet bir cesettir denilirse yetiştirdiği bir büyük adam onun ruhudur, demelidir." (s. 72)

Hâzım ve Kâmil Bey’leri devlet ve düzene karşı eleştiri yapmaya

\footnotetext{
10 Yahyâ Kemal de "kaht-l ricâl"in, Osmanlı Devleti'nin önemli problemlerinden biri olduğunu düşünür. Ona göre Osmanlı'nın, ne mektep ne de başka herhangi bir kurumun eksikliğinden kaynaklı sıkıntısı vardır. Kurumlaşmayı sağlayan Osmanlı, bu kurumları işletecek insan bulamamaktadır. Çünkü mekteplerde ve çeşitli dairelerde, cahil insanların sözü geçmektedir. Yahyâ Kemal bu durumdan daha çok, bahsi geçen cahil kitlenin, ülkenin yetişmiş elemanlarını da sindirebilmesine üzülür. Yazara göre bu sindirme işine dur denmeli, kötünün içindeki iyi kitle ayıklanmalı, ziraatten eğitime, ticaretten sanata, ülkenin yeniden inşas1, bu ehliyet sahibi insanlara bırakılmalıdır. (1990, s. 241-242)
} 
taşıyan neden, gelinen noktadır. Osmanlı Devleti'nde düzen değişmiş, rağbet ve değeri, "falanın oğlu olanlar" (s. 63), "etek öpenler" "müdahane edenler" (s. 63) görmeye başlamıştır. Hâzım'ın ve oyun kahramanlarından Nuri'nin, kalemlerinde karşılaştıkları haksız tutumun nedeni, sayılanları yapmayışlarıdır. Süreyya Bey'in büyük beceri sergilediği bu davranışlara karşı da şiddetli tepkileri Hâzım ve Kâmil Bey’ler geliştirir. Örneğin Kâmil Bey'e göre ancak değerli insanların etekleri öpülür. (s. 62) Bunu Süreyya Bey'in yüzüne söyleyen, ama onun üstüne alınmayacağını bilen Kâmil Bey, Süreyya Bey ile ülkenin geleceği konusunda da tartışır. Siyasetin ancak ülkenin büyükleri için meşru olması gerektiğini düşünen Süreyya Bey, onların dahi, firsat zamanlarını kaçıran ülkeyi diriltemeyeceğine inanmaktadır. (s. 68, 69) Kâmil bu fikirlere karşı çıkar ve ülkenin hâlâ firsatları yakalama şansı olduğunu ifade eder. Yeter ki ülke insanları üstlenmeleri gereken sorumluluktan kaçmasınlar. "Herkes efrâdından bulunduğu milletin saye-i satvetinde yaşadı̆̆ devletin izzetinde zilletinde haline göre hissedâr" olduğuna göre, sorumluluk herkese aittir. (s. 69) Büyük küçük herkes ortak hedeflerde birleşmeli, "hem kendinin hem umumun husul-i saadeti" için elinden geleni yapmalıdır. (s. 70) İşte o durumda, zaman, Osmanlı toplumuna saadet ve ikbal getirebilecektir. (s. 70)

Oyunda ya sarhoşken ya ağlarken tespit sunan Hâzım, zayıf karakterine rağmen hedefler belirleyebilmektedir. O bu yönüyle, toplumuna yabancılaşan ve duyarsızlığı artan insan tipinin örneği Süreyya'dan, uzaktır. Hâzım, dünya üzerindeki yerini sorgulayabilen, ülkesi ve geleceği için umut besleyen Kâmil Bey'e yakındır. Bu nedenle de öleceğini düşündügü bir anda vasiyetlerini ona eder. Kendisi de babası gibi ölecektir, fakat devletin "milli gayretler" içinde olan bu insanlara ihtiyacı bitmeyecektir. Bu gayret, kişilerin yüzünde nur gibi parlamaya devam edecektir: "A ğlamakla kaybedeceğiniz vakti halinize düşmanı güldürmemeye hizmet edecek tedbirlere sarf edin. Sadıklarımızdan ölmeyince ayrılmayan gayret-i milliye ölürken de nur u iman gibi yüzünüzde parlasın dursun." (s. 55)

\section{Heder'de Edebî Boyut}

Heder, toplumsal boyuttaki değerlendirmelerin, kimi zaman edebî değerlendirmelerle zenginleştirildiği bir yapı arz eder. $\mathrm{Bu}$ nedenle oyunun arka planında yer alan bu edebî değerlendirmelerin tahlili önemlidir.

\subsection{Halk Edebiyatına Yönelik Değerlendirmeler}

Celâl Tarakçı, Muallim Naci'nin halk edebiyatına karşı menfî bir tavır içinde olduğunu iddia eder ve bu iddiasını örneklerle ispata çalışır. Yazarın seçtiği örneklerde, Âşık Ömer ve Nasreddin Hoca isimleri 
geçmektedir. (1994, s. 232-236)

Anılan isimler Heder'de de geçer ve Naci'nin halk edebiyatına karşı tavrını ortaya koyar. Anlaşılan o ki bu tavır gerçekten de menfîdir. Oyunun renkli kişiliği Nuri Bey, birinci sahnede rakı masasındayken bir fikra anlatacağını söyler, fakat lafı uzatınca bir türlü fikraya başlayamaz. Sabırsızlanan Kâmil Bey, Nuri Bey'i uyarınca Nuri Bey, kendisini haklı çıkarmak için Nasreddin Hoca örneğini verir. O, Nasreddin Hoca gibi sadece gülünüp geçilecek bir fikra anlatmayacaktır, bu nedenle ön hazırlık yapması doğaldır: “... Hem benim söyleyeceğim fikra Nasreddin Hoca meseli değil ki sade gülmekle geçilsin, neticesinden bayağl gülmeyi men' edecek derecede manâlar çıkar." (s. 17) Bu ifadelerden yola çıkıldığında, Tarakçı'nın, Muallim Naci'nin, Nasreddin Hoca fikralarının mana dolu olduğunu çözemediği yolundaki tezi d doğru gözükmektedir. (1994, s. 235) Kültürümüzde, Nasreddin Hoca fikralarının, ihtiyaç duyulan her kriz anında çözüm bulabilecek unsur olarak işlev görmesi bunun kanıtıdır.

Yukarıda bahsi geçen rakı sofrasında Kâmil Bey de şiir anlayışını açıklar. Bunu, Nuri Bey eski şiirin hayal dünyasını eleştirdiği için yapar. Kâmil Bey'e göre söz konusu hayal dünyasının varlığı önemlidir, çünkü "şiir biraz da muhayyel olmalı"dır (s. 20) Kâmil Bey, bu düşüncesini bir örnekle zenginleştirmek ister ve sözlerinin devamında "Artık Aş̧ı Ömeranesi de hiç çekilmez" der. (s. 20) Verilen örnek, Muallim Naci'nin, halk şiirini kuru bulduğunu, küçümsediğini göstermektedir. Nitekim şair, Tercüman-ı Hakîkat'e gönderdiği ilk şiirlerinin, "Aşık Ömer'cesine" değerlendirilmesinden korkmuş, bu tarz bir şöhret kazanmaktansa meçhul bir edip olarak kalmayı tercih edeceğini söylemiştir. (Aktaran Tarakçı, 1994, s. 232)

\subsection{Edebiyatımızda Yabancı Etkiler}

Oyunda Kâmil Bey, Hâzım Bey'in yazdığı bir gazeli değerlendirirken Farsça bir beyit okur. (s. 66) Muhatabı, Hâzım'ın zıt karakteri Süreyya Bey'dir. Süreyya Bey bu beyitten sonra Kâmil Bey'in hedefi hâline gelir ve Kâmil Bey mesajlarını onun üzerinden verir. Çünkü Süreyya Bey, Hâzım Bey'in gazelini hiciv dolu olduğu için beğenmemiş, hatta bu gazeli şiir olarak kabul etmemiş̧tir. Bunun üzerine Kâmil Bey, önce Hâzım'ın şiirini över, sonra okuduğu Farsça beyti yorumlar. Yorumundan sonra da Süreyya Bey'e; "İhtimal ki siz bunu da beğenmezsiniz" der. (s. 66) Kâmil Bey'in bu yargısının nedeni, dönemde "Acemceyi, Arapçayl" beğenmemek gibi bir modanın söz konusu olmasıdır. Ama o, modayı benimsemez ve kültür ve edebiyatımız üzerindeki Acem, Arap etkisinin 
inkâr edilemeyeceğini işaret eden ifadeler kurar: "İhtimal ki siz bunu da beğenmezsiniz. Çünkü Acemceyi de beğenmemek moda oldu. Doğru söz, güzel söz nece olursa olsun beğenirim. Arap'ı beğenmeyelim. Acem'i beğenmeyelim. Ya bu hal ile şeytan gibi kendimizi mi beğenelim?" (s. 66)

Kâmil Bey'in sitemleri, Muallim Naci'nin bu konudaki düşüncelerinden izler taşır. Çünkü Muallim Naci “Arap dilinin 'vüs'atinin' herkesçe bilindiğini" düşünür ve "bu lisanın edebiyatından istifade etmekliğimiz gerektiğini ileri sürer." (Tarakçı, 1994, s. 227) Fakat Muallim Naci bu konuda sorgusuz bir bağlılık içinde değildir. O, Arap ve İran edebiyatının ürünleri içinde, asra uygun olmayanların da bulunduğunu bildiği için, edebiyatımızı geliştirecek ürünlere değer verilmesi gerektiğini düşünür. (Tarakçı, 1994, s. 225-230)

Kâmil Bey ile Süreyya Bey arasındaki konuşmanın devamında, Avrupa edebiyatlarından da bahis söz konusudur. Kâmil Bey, Farsça'nın, Arapça'nın beğenilmemesinden yola çıar ve bir eserin sırf "Voltaire ya da Shakespeare" yazdı diye beğenilmesini eleştirir. (s. 66) Ona göre Voltaire'in eserlerindeki yanlışlar, bu yüzden görmezden gelinmektedir. Fakat bu sözler, Kâmil Bey'in Avrupa edebiyatının öğrenilmesini istemediği şeklinde yorumlanmamalıdır. Onun karşı çıktığı, bir eserin, yazar veya şairinin kim olduğundan yola çıkılarak değerlendirilmesidir. Çünkü o, daha sonra Ahmet Bey ile yaptığı konuşmada, yabancı etkisinin, kıvamında olursa, ülkenin ve edebiyatımızın yararına olacağını ifade eder. Oyundaki tüm diyaloglarında olduğu gibi burada da Muallim Naci'nin, Istılahat-1 Edebiyye'sinde işlediği (t.y.: s. 73), tiyatro tarzında yazılan edebî eserlerde şahısların, durumlarına uygun olarak söz söylemesi gerektiği yolundaki tezine hayat veren Kâmil Bey, Osmanlı toplumunun dış dünyaya kapalı olmaması gerektiği görüşünden yola çıkar. Ona göre Osmanlı toplumu yabancı dil bilmez ise Avrupa'nın "mehasin ve maarif"'ini takip edemez. (s. 84) Bu, Osmanlı'nın, dostunu düşmanını tanıyamaması, fayda göreceği bir kültüre sırt çevirerek, içine kapanması demektir. Görüldüğü gibi Kâmil Bey, Avrupa lisan ve kültürüne karşı değildir. Karşı olduğu şey, bu kültüre körü körüne bağlılıktır. Ona göre Batı kültürü, millî değerler inkâr edilerek, basit bir taklitçilik boyutunda algılanırsa fayda değil, zarar getirir: "Ecanibin ahvali lisanların bilmekle anlaşıllır. Ahval anlaşllınca dost düşman fark olunur. Ona göre hareket edilir. Avrupa'daki maarif ve mehâsin alınır(sa) büyük büyük faydalar görülür. Bilmek elbette bilememekten hayırlıdır. Fakat, maarif ve mehâsin-i milliye bir tarafa birakılır da sade Frenklik öğrenilirse buyurduğunuz gibi pek muzır olur" (s. 84) 
Kâmil'in bu sözleri Ahmet Bey'in hoşuna gider. Fırsat bulmuşken o da gençlerin, Müslümanlığını, milliyetini unutarak, Frenklik modası gütmelerinden duyduğu rahatsızlığı dile getirir. (s. 84)

İkili gençlerin tutulduğu bu yanlış modanın, Hâzım'1 etkilemediği konusunda hemfikirdirler. Onlara göre Hâzım, Doğu dünyasını da Batı dünyasını da bilen, her iki kültürü de millî değerleri ile sentezlemek gerektiğini düşünen "hamiyyetli gençlerdendir." (s. 84) Ayrıca Hâzım gibi Nuri de özüne sahip çıkanlardan olduğu için, bu konuda hâlâ umut vardır. Nuri, dinleyeceği müziğin alaturka olmasını istediği rakı meclisinde, umudun ismi olur ve "Ben Osmanliyım... Türk'üm. Alaturka isterim. Öyle... Osmanlılık, Türklüğ̈̈ şeyn edenlerden değilim.” der. (s. 31)

Oyunda, konuyla ilgili her vak'a ve konuşmanın okuru taşıdığ 1 boyut, Muallim Naci'nin Osmanlı toplum ve edebiyatının içinde bulunduğu durgunluk konusundaki tezleridir. Osmanlı toplumu ve edebiyatçısı, Doğu ve Batı dünyasına sırt çevirmeden, bu kültürlerin işe yarayacak unsurlarını ithal etmelidir. Bunu yaparken kıstas, millî değerlerden vazgeçmemek, millî menfaatleri öncelemek olmalıdır. Heder bu açıdan, Aytaş'ın, "Tanzimat tiyatrosundaki eserlerin çoğu tezlidir bu eserlerde tenkit edilen veya savunulan birer problem vardır" görüşünü yansitmaktadır. (2015, s. 99)

\subsection{Dönem Şiiri ile İlgili Değerlendirmeler}

Oyunun ilk sahnesinde, Nuri Bey'in kalemdeki düzeni eleştirirken araya nazım parçaları yerleştirmesi Kâmil Bey'in hoşuna gider. (s. 19) Sonrasında Nuri Bey şiir anlayışını açıklamaya başlar. O, fikirlerini şiirle de açıklayabilmekte ve bunu yaparken akıldışı, doğaüstü herhangi bir motiften yararlanma ihtiyacı hissetmemektedir: "Efkârımı nazım ile de pek güzel ifade edebilirim. Şiirimde öyle akıldan, tabiattan hariç şeylerden dem vurmam. Bir kahramana mızrağının yahut süngüsünün ucuyla gökteki yıldızların bağrını deldirmem. Bir seyf-i sârime yerin altındaki biçare öküzü iki parça ettirmem." (s. 20) Görüldüğü gibi Nuri Bey'in hedefi, Divan şiirinin hayal dünyasıdır ve bu yönüyle o, Muallim Naci'nin sözcüsüdür. Çünkü Muallim Naci de şiirin "muvafik-ı akl u tabiat" olmasını arzu etmektedir. (Aktaran Tarakçı 1994, s. 221) Muallim Naci'ye göre bir nesne veya kavramın tavsifinde dikkatli olmak gereklidir. Tavsif gerektiği kadar mübalağa içermeli, gerektiği kadar tabiî olmalıdır. "Tavsiflerde, yerine göre tumturakll, parlak sözler ve cümleler kullanmak iyi olmakla beraber... durumu tabiîlikten çıkarmak kötü olur" diyen Naci, aşırı mübalağa içeren ifadelerden artık nefret edildiğini belirtir. (t.y., s. 108-109)

Nuri Bey'in bu sözleri, oyunun edebî boyutunun üzerine inşa 
edildiği önemli bir meseleyi, eski-yeni tartışmasını alevlendirir ve Nuri'ye ilk karşı çıkan Kâmil Bey olur. Kâmil Bey'e göre dönemin edebiyat ortamlarındaki bir başka moda da eskiye, eskilere veryansın etmektir. Ona göre cehaletlerinin farkında olmaya gençler, eski şiire hücum ederken hem dürüst değildirler hem ortaya koydukları eserlerde eskinin muvaffakiyetini yakalayamazlar: "Yavrum yeni şairler! Hem eslafin asarını dürüstçe okuyamazlar, hem de onları tezyife kalkışırlar. Asar-ı Cedide denilen şeyleri de görüyoruz. Ne tadı var ne tuzu!" (s. 20)

$\mathrm{Bu}$ sözlerle roller değişmiş, Muallim Naci’nin yeni sözcüsü Kâmil Bey olmuştur. Daha doğrusu Muallim Naci, fikirlerini farklı kahramanları aracılığı ile açıklamaya başlamıştır. Çünkü yukarıda şiirin akla, tabiata uygunluğunu şart koşan Naci, eski şiirin hayal dünyasını eleştirir, fakat bütünüyle redde yönelik bir tavır takınmaz. Muallim Naci, Divan şairlerinin tümünü aynı hükümlerle değerlendirmez. "Her dönemin edebiyatında iyi ve kötü, güzel ve çirkin eserlere tesadüf edilebileceğini belirterek, iyiyi kötüden, güzeli çirkinden ayırmak gerektiğini israrla vurgular." (Erbay, 1997, s. 357) Muallim Naci için önemli olan, bütün dış etkilerde olduğu gibi, Divan şiiri ile de sağlıklı ilişkiler kurabilmektir. Nitekim oyunda Nuri Bey bu ilişkilerin rengini şöyle niteler: "Eslafi tezyif etmiyorum. O zamanların beslediği fikirleri beğenmiyorum. Onların asar-ı hakîm-ânesi niçin beğenilmesin? Ahlafa niçin hocallk etmesin." (s. 20) Demek ki geçmiş edebî birikimi yok saymak yerine, ondan yarar sağlamaya çalışmak, dönem şiirinin zenginleşmesi yolunda bir teklif sayılmalıdır.

Nuri Bey bu sözlerinin devamında, şiirinin, geçmişe değer veren üstatlar tarafından da beğenileceğini söyleyerek kendisini över. (s. 21) Ona göre kendisi, üstatların bile hoşuna gidecek sözleriyle, dönem gençlerinden farklıdır. Çünkü dönemin genç edebiyatçıları vezinsiz, yalanlarla dolu, saçma sözler edip, üstüne bir de edebiyat öğretmeni kesilerek övündükleri için, Nuri'nin değerinde değildirler: "Ben öyle lafz u manası galat-âmîz belki de vezinsiz sekiz satır şey yazarak i'lân-l cehl edip de şairim diye kurulan, sehhâka hikâyesi yolunda birkaç parça türrehât meydana çıkarıp da nevresîde-gân-ı millete talim-i edeb eder müellif kesilen hôd-fürûşlardan değilim!"'11 (s. 21)

\footnotetext{
${ }^{11}$ Muallim Naci, “Üdebâ-yı Zamâne” başlıklı şiirinde de benzer düşüncelerini ifade eder. Ona göre, kuralsız, yalanlarla dolu, faydasız, anlamsız sözlerin, terakki adı altında değerlendirildiği bir ortamada, söylenenler insanı ancak, hayret içinde bırakabilmektedir: Eflâzına baksam bu sözün kâidesizdir/ Ma'nâsına baksam o dahi fâidesizdir... Lâfżnda galat çokça ise tarz-ı nevîndir/ Ma'nâsı dahî yoksa var â sihr-i mübîndir/ Dîvânece sözler mi
} 
Bununla birlikte Nuri Bey ne kadar kendisini överse övsün, haddini de bilen bir gençtir. Örneğin Hâzım Bey'in ilim irfan bakımından kendisinden üstün olduğunu bilir. (s. 21) Onun kabullenemediği, "şık beylerin" kendisinden aşağıda olmalarına rağmen değer görmeleridir. (s. 21) $\mathrm{Bu}$ "şık beyler"i Nuri Bey, oyunun bir başka yerinde de alafranga düşkünlükleri nedeniyle eleştirir. (s. 31) Dolayısıyla "şık bey" kavramı oyunda, "alafranga düşünü fakat zevksiz, kendini öven fakat ortaya koyduğu eserlerde övünülecek bir unsur bulunmayan kişi" anlamına gelmektedir ve görünen o ki Naci'nin hayatında bu insanların önemli tesiri söz konusudur. Çünkü şair, bulunduğu meclislerde bu “şık beyler"in cahilliklerini, zevksizliklerini yüzlerine vurmaktan çekinmemiştir. (Tarakçı, 1994, s. 257-258)

Ayrıca onun, Nuri Bey aracılığı ile şık beylerin kendisinden daha çok değer görmesine yaptığı eleştiri de hayatından izler taşır. Nuri Bey'in işaret ettiği "şık bey" Abdülhak Hâmid Tarhan olup, iki şair arasında bu tarz bir muhasebe gerçekten de söz konusu olmuştur. Öyle ki Muallim Naci, Abdülhak Hâmid'in şiirlerini Tercüman-ı Hakîkat'te yayımlayan, Hamid'i çok öven Recâizâde Mahmut Ekrem'e kızgındır ve Hâmid'e karşı menfî bir tavır içindedir. $\mathrm{Bu}$ nedenle ona göre kendisinin bir şiirini Recaîzâde'ye, Hâmid imzasıyla gönderirse, Recâizâde derhal takdir edecek; Hâmid'in bir şiirini Muallim Naci imzasıyla gönderirse derhal hicvedecektir. (Aktaran Tansel, 1953, s. 184)

Muallim Naci, eserin değil, ismin değer gördüğüne dair eleştirisini de oyununda Nuri Bey aracılığıyla dile getirir. Nuri Bey bu konuda eski-yeni ayrımı yapmadan, herhangi bir eserin, sırf Nef'înin veya sırf Fuat Paşa'nın imzasını taşıdığ 1 için değer görmesine kızar. (s. 28) Ona göre kendisinin bir şiiri, Fuat Paşa imzası ile naklonursa okunur ve alkışlanır, Nuri imzasıyla naklonursa kimsenin dikkatini çekmez. Bu durum, dönemde sahte şöhret sahiplerinin, yetenekli gençlerin hakkını gasp etmesi anlamına geldiği için, Nuri bu bahsi "temyiz isterim temyiz" nidalarıla kapatır, fakat arzusu karş111k bulmaz. (s. 28)

Yukarıda, oyunun Divan şiirine bağl1lık noktasında örnek isminin, Kâmil Bey olduğunu söylemiştik. Fakat Kâmil Bey bile bu konuda çelişki yaşıyor gibi gözükmektedir. O, Süreyya Bey ile yaptığı konuşmada, Hâzım Bey'in hiciv dolu gazelinin beğenilmemesi üzerine, "sıkıştırdım sarıldım 
öptüm aldım koynuma yattım" tarzı şiirlerin beğenildiği bir ortamda Hâzım'ın hicvinin elbette ki değer görmeyeceğini ifade eder. (s. 65) Sözler Divan şiirinin yapılandığ1 zemini hatırlattığ1 için, Kâmil'in Divan şiirini eleştirdiğine dair doğan düşünce, aslında oyun bütünlüğü içinde eriyen bir eleştiridir. Çünkü, Fuzûlî’den "Koca Fuzûli", Nailî’den "Nailî metin şeydir" diye bahseden odur. (s. 27) Ayrıca Kâmil Bey, Hâzım Bey'in hastalık haberini alınca onun için iyi dilekte bulunur ve "Ah çocuk! İş̧allah kalemin umuma daha pek büyük hizmet eder" der. (s. 73) Dolayısıla kahramanların edebiyatımızdaki yabancı tesirler ve eski-yeni tartışmaları konusundaki tüm söyledikleri ve zaman zaman düştükleri çelişkiler, Muallim Naci'ni edebî görüşlerinden farklı izler taşıdıkları için kabul edilebilir niteliktedir. Çünkü Muallim Naci körü körüne red veya kabul taraftarı değildir. Doğu ve Batı kültürlerinin millî bünyeye uygun tarafları ile iletişime geçmek gerektiği konusundaki doğru tespiti, eski-yeni tartışmasında da ön plandadır. O, eski şiirin reddinden değil, yeni nesillere ayıklanarak nakledilmesinden yanadır. Yeni eğilimleri ise şiirimiz açısından gerekli ve önemli kabul eder. Onun bu tavrı Tanzimat' 1 birinci neslinin edebiyata sosyal sorumluluklar yüklemesi anlayışı ile de örtüştüğü için önemlidir. Kalem erbabı, Hâzım için yapılan iyi dilekte olduğu gibi, önce umuma hizmet etmelidir ve görüldüğü gibi Heder, hem sosyal hem edebî boyutuyla, bu hizmet için bir araç olsun diye kurgulanmıştır. Celâl Tarakçı'nın, Muallim Naci'nin “Türk edebiyatının yükselmesi için bütün güzelliklerden yararlanılmasını istediğì" yolundaki tezi, bu yönüyle hak teslimiyeti anlayışının ürünüdür. (1994, s. 259) Yine İbnü'l Emin Mahmut Kemal İnal'ın, Naci hakkındaki suçlamaları özetledikten sonra, Naci için:

\section{Gerçi hakkında kimi şöyle kimi böyle dedi Fazl ü irfânı müsellem, yüce bir şâir idi}

beytini kurması da aynı anlayıştan izler taşımaktadır. (İnal, 2000, s. 1434)

\section{Sonuç}

Heder, 1326 yılında İkdam Matbaası'nda basılmıştır ve seksen sekiz sayfadan ibarettir. Eserin vak'a örgüsü çok güçlü olmadığı için, şahıs kadrosu da kalabalık değildir. Buna paralel biçimde, eserin zaman ve mekân unsurlarına yaklaşım biçimi de zayıftır. Bu yönüyle, Heder, döneminden ayrık bir eser değildir. Çünkü sayılan özellikler, Tanzimat dönemi tiyatro oyunlarının çoğuyla ortaktır. Heder'in, dönemde bol miktarda kaleme alınan melodram türü eserlerden biri olması, bu savın bir başka ispatıdır. Yazar, eserinde birtakım öğretileri dillendirmek amacındadır. Çünkü Heder'in üzerine inşa edildiği sosyal ve edebî öğretiler, Muallim Naci'nin hayat 
algısından ve edebî görüşlerinden izler taşımaktadır. Toplumsal dejenerasyonda insanın rolünü önemseyen yazar, sosyal boyuttaki tespitlerinde, insanın bu dejenerasyonun önüne nasıl geçeceğine dair öneriler sunmaktadır. Oyunun başkişisi heder olmasına rağmen, umut tükenmemiştir.

Toplumların sosyal yaşam ve düzenlerinde sanatın önemli bir gösterge olduğu gerçeği, Muallim Naci'yi, oyununda sanatsal meselelere değinme zorunluluğuna da taşımış gibidir. Yazar bu noktada, edebiyatımızın nasıl zenginleşeceği ve geleceğe kalacağ 1 yolunda eleştiri ve tekliflerini bir arada sunar.

Bununla birlikte, Heder, çalışmanın boyutları nedeniyle değinilmeyen birçok aksaklık da barındırmaktadır ve eserin dili bunların başlıcasıdır. Topluma edebiyat aracılığıyla ışık tutma amacını, eserin ağır dili ile sekteye uğratan yazar, belli ki aynı zamanda içinden geldiği geleneği reddedemeyeceğini ispat için, sanatsal olabilme amacı da güder.

Çalışmada varılan tespitler, Heder'in Muallim Naci'nin edebî şahsiyetine yönelik hücumlar nedeniyle unutulduğu savını ortaya koymaktadır. Çünkü Heder' in tematik yapısı ve amacı, dönemdeki oyunlarla eştir.

\section{KAYNAKLAR}

Akı, N. (1989). Türk tiyatro edebiyatı tarihi I. İstanbul: Dergâh Yayınları.

Akyüz, K. (1985). Batı tesirinde Türk şiiri antolojisi. İstanbul:İnkılâp Kitabevi.

And, M. (2004). Başlangıcından 1983'e Türk tiyatro tarihi. İstanbul: İletişim Yayınları.

Aytaş, G. (2015). Tanzimat devri Türk tiyatrosu. M. K. Özgül (Ed). Türk Edebiyat Tarihine Bir Baklş içinde ( ss.75-100). Ankara: Kurgan Edebiyat Yayınları.

Beyatlı, Y. K. (1990). Mektuplar Makaleler. İstanbul: İstanbul Fetih Cemiyeti Yayınlar1.

Çalışlar, A. (1993). 20. yüzyılda tiyatro. İstanbul: Mitos BOYUT Yayınları.

Çalışlar, A. (2009). Tiyatronun ABC'si. İstanbul: Say Yayınları.

Çamurdan, E. (2015). Tanzimat dönemi Türk tiyatrosu. İstanbul: Habitus Yayıncılık.

Çetin, N. (2006). Muallim Naci. İ. Parlatır (Ed.) Tanzimat Edebiyatı içinde (ss. 651701). Ankara: Akçă̆ Yayınları.

Çetişli, İ. (2009). Metin tahlillerine giriş 2. Ankara: Akçağ Yayınları.

Enginün, İ. (1993). Namık Kemal ve tiyatro. Doğumunun Yüzellinci Yılında Namık Kemal içinde (ss. 13-24). Ankara: Türk Tarih Kurumu Basımevi.

Enginün, İ.,\& Kerman, Z. (2011). Yeni Türk Edebiyatı Metinleri 3. İstanbul: Dergâh Yayınları.

Erbay. E. (1997). Eskiler ve Yeniler. Erzurum: Akademik Araştırmalar.

Gökçek, F. (2007). Bir tartışmanın hikâyesi Dekadanlar. İstanbul: Dergâh Yayınları. İnal, İbnü’l Emin Muhammed Kemal. (2000). Son Asır Türk Şairleri. 3. (Hzl. 
Hidayet Özcan). Ankara: Atatürk Kültür Merkezi Başkanlığı Yayınları.

Kaplan, M. (1998). Şiir tahlilleri I. İstanbul: Dergâh Yayınları.

Muallim Naci (1326). Heder. İstanbul: İkdâm Matbaası.

Muallim Naci (t.y.). Istılahat-ı Edebiyye. (Hzl: Alemdar Yalçın, Abdulkadir Hayber) Ankara: Akabe Yayınları.

Muallim Naci (1998). Mektuplarım. (Hzl: Ramazan Kaplan) Ankara: T. C. Kültür Bakanlığı Yayınları.

Namık Kemal (2005). Celâleddin Harzemşah. (Hzl. Oğuz Öcal). Ankara: Akçağ Yayınları.

Parlatır, İ. (2006). Şinasi. İ. Parlatır (Ed.) Tanzimat Edebiyatı içinde (ss. 71-126). Ankara: Akçağ Yayınları.

Sevengil, R. A. (2015). Türk tiyatrosu tarihi. İstanbul: Alfa Basım Yayım Dağıtım.

Şener, S. (1991). Dünden bugüne tiyatro düşüncesi. Eskişehir: Anadolu Üniversitesi Yayınları.

Tanpınar, A. H. (1988). 19 uncu asır Türk edebiyat tarihi. İstanbul: Çağlayan Kitabevi.

Tansel, F. A. (1953) Muallim Naci ile Recaizade Ekrem arasındaki münakaşalar ve bu münakaşaların sebep olduğu edebî hadiseler. 06.01.2016 tarihinde www.journals.istanbul.edu.tr/iuturkiyat/article, adresinden erişildi. s. 159206

Tiyatro Bibliyografyası 1859-1928 (1967). (Hzl. Türkân Poyraz, Nurnisa Tuğrul) Ankara: Milli Eğitim Basımevi.

Tarakçı, C. (1994). Muallim Naci Efendi. Samsun: Furkan Kitabevi.

Töre, E. (2016a). Geleneksel Türk tiyatrosu. İstanbul: Kesit Yayınları.

Töre, E. (2016b). Modern Türk tiyatrosu. İstanbul: Kesit Yayınları.

Uçman, A. (1998). Muallim Naci. İstanbul: Toker Yayınları.

Uçman, A. (2006). Namık Kemal. İ. Parlatır (Ed.) Tanzimat Edebiyatı içinde (ss. 201-288). Ankara: Akçağ Yayınları.

Ulçugür, İ. (1982). Muallim Naci'nin 'Heder'i üzerine. Yazko Edebiyat, 16, 123137.

Yalçın, A. (2002). II. Meşrutiyette tiyatro edebiyatı tarihi. Ankara: Akçağ Yayınları. 